\title{
Article \\ Designing Environmental Messages to Discourage Red Meat Consumption: An Online Experiment
}

\author{
Alice Wistar ${ }^{1}$, Marissa G. Hall ${ }^{2,3,4}$, Maxime Bercholz ${ }^{4}$ and Lindsey Smith Taillie ${ }^{4,5, *}$ \\ 1 Program in Global Health and Health Policy, Center for Health and Wellbeing, Princeton School of Public and \\ International Affairs, Princeton University, Princeton, NJ 08544, USA; alicewistar@gmail.com \\ 2 Department of Health Behavior, Gillings School of Global Public Health, University of North Carolina at \\ Chapel Hill, Chapel Hill, NC 27599, USA; mghall@unc.edu \\ 3 Lineberger Comprehensive Cancer Center, University of North Carolina at Chapel Hill, \\ Chapel Hill, NC 27599, USA \\ 4 Carolina Population Center, University of North Carolina at Chapel Hill, Chapel Hill, NC 27516, USA; \\ bercholz@email.unc.edu \\ 5 Department of Nutrition, Gillings School of Global Public Health, University of North Carolina at Chapel Hill, \\ Chapel Hill, NC 27599, USA \\ * Correspondence: taillie@unc.edu
}

check for

updates

Citation: Wistar, A.; Hall, M.G.;

Bercholz, M.; Taillie, L.S. Designing

Environmental Messages to

Discourage Red Meat Consumption:

An Online Experiment. Int. J. Environ.

Res. Public Health 2022, 19, 2919.

https://doi.org/10.3390/

ijerph19052919

Academic Editors: Roberto Alonso González Lezcano, Francesco Nocera and Rosa Giuseppina Caponetto

Received: 10 February 2022

Accepted: 28 February 2022

Published: 2 March 2022

Publisher's Note: MDPI stays neutral with regard to jurisdictional claims in published maps and institutional affiliations.

Copyright: () 2022 by the authors Licensee MDPI, Basel, Switzerland. This article is an open access article distributed under the terms and conditions of the Creative Commons Attribution (CC BY) license (https:// creativecommons.org/licenses/by/ $4.0 /)$.

\begin{abstract}
Reducing red meat consumption in high-consuming countries is critical for mitigating climate change and preventing chronic disease. This study tested the effectiveness of messages conveying the worsening or reduction of environmental harms at discouraging red meat consumption. 1078 U.S. adults viewed seven messages in an online survey highlighting the reduction or worsening of environmental harms associated with eating red meat (between-subjects factor) and rated the messages on how much they discouraged them from wanting to buy beef. Each message highlighted a different environmental harm: deforestation, climate change, water shortages, biodiversity loss, carbon footprint, greenhouse gas emissions, or environment (within-subjects factor). No statistically significant difference was found between the reduction and worsening of environmental harms conditions for most topics, though the worsening of harms frame slightly outperformed the reduction of harms frame for the 'environment' topic. 'Environment' was also the message topic that elicited the strongest response from participants overall. Latino participants, those with more than a high school degree, and those who consume beef once a week or less rated messages as more effective than nonLatino participants, those who completed high school or less, and those who consumed beef more than once a week. Future research should explore the effect of messages on behavioral outcomes.
\end{abstract}

Keywords: vegetarianism; goal framing; emphasis framing; sustainability; meat consumption; environmental behavior; health communication

\section{Introduction}

Reducing red meat consumption in countries with high levels of consumption was identified by the 2019 EAT-Lancet commission as a strategy that would benefit both the environment and human health [1]. Recent meta-analyses show the associations between red meat (beef, lamb, pork, and other mammalian meat) and colorectal cancer [2-4], type II diabetes [5], stroke [6], coronary heart disease [6], heart failure [6], obesity [7], and allcause mortality [8,9]. Because of these relationships, organizations including the American Cancer Society recommend limiting red meat consumption in favor of poultry, fish, or plant-based proteins $[10,11]$. Substituting whole, plant-based foods such as nuts, legumes, and whole grains for red meat is associated with a lower risk of type II diabetes [12,13] and mortality risk [14] and can lead to an increase in life expectancy [15]. One meta-analysis concluded that reducing or eliminating consumption of red or processed meat would also reduce the risk of stroke, coronary heart disease, and heart failure [6]. 
In addition, livestock contributes $14.5 \%$ of all anthropogenic GHG emissions [16], beef alone representing $41 \%$ of these emissions [16], and is the single most significant source of methane emissions [17]. Livestock also uses $30 \%$ of the planet's ice-free terrestrial surface [18] and is a leading cause of biodiversity loss [16-19], deforestation [16-18,20,21], aquifer depletion and water shortages [17,22], eutrophication [23], terrestrial acidification [23], and land degradation and pollution [16,17,19,24].

In the U.S., where beef consumption is the second highest in the world [25] and where beef accounts for nearly half of land-use and GHG emissions associated with diets [26,27], reducing red meat consumption could yield significant environmental benefits [19,26-34]. An analysis from the World Resources Institute showed that reducing beef consumption to the world average level in regions such as the U.S. where beef consumption is above average could spare 300 million hectares of pasture [27], an area nearly the size of India. More recent research shows that annual agricultural production emissions of high-income countries' diets could be reduced by $61 \%$ if their populations adopted the EAT-Lancet planetary health diet [35], which limits red meat consumption to $98 \mathrm{~g}$ per week [36]. A gradual phase out of all of animal agriculture, while unlikely, could achieve half of the net GHG emission reductions necessary to limit global warming to $2{ }^{\circ} \mathrm{C}$ above preindustrial levels, a goal set at the Paris Agreement, with the phasing out of beef accounting for $47 \%$ of those GHG reductions [37]. Indeed, limiting global temperature rises to $2{ }^{\circ} \mathrm{C}$ above preindustrial levels is not possible without GHG reductions from the food system [38]. Other specific environmental benefits of diets lower in red meat include reduced clearing of agricultural land [39], global water consumption [22], extinction risk for mammals and birds [39], terrestrial acidification [23], and eutrophication [23].

Given high levels of red meat consumption in the U.S., one challenge relates to identifying effective strategies to reduce consumption. Messaging has been an effective strategy to change health behaviors such as smoking [40], sugar-sweetened beverage (SSB) consumption [41], and alcohol use [42]. Although most public health messages about food have focused on individual health outcomes, messages that focus on the environment are promising. Considering that public awareness and concern around the threats of climate change are increasing [43], particularly among young people [44], environmental messaging may further increase awareness about red meat's environmental harms. In an online experiment with 590 German adults, Cordts et al. (2014) found that providing information about meat's environmental harms increased participants' intention to reduce their meat consumption in the future [45]. Thus, environmental messaging may also help change meat consumption behaviors. Yet, relatively little is understood about the types of messages that are most effective at discouraging red meat consumption.

Message framing, or the particular way in which information is communicated and emphasized, is an important tool used to maximize the impact of messages on individuals ${ }^{\prime}$ thoughts and behaviors. Though little research explores framing in the context of meat reduction messaging strategies specifically, message framing has been shown to alter individuals' behavioral intentions and attitudes on environmental issues more broadly $[46,47]$.

There are numerous types of message framing. Goal framing is one such type that involves emphasizing either the advantages of engaging in a target behavior (e.g., composting can help the environment) or the disadvantages of not engaging in a target behavior (e.g., not composting can hurt the environment) [48]. Prior research suggests that negatively framed messages are more effective than positively framed messages due to a negativity bias wherein individuals tend to dislike losses more than equivalent gains [49-51]. A recent systematic review of 61 studies finds that emphasizing the negative outcomes of an environmentally relevant decision is more likely to prompt a change in behavior and intentions to change behavior, whereas emphasizing the positive outcomes of an environmentally relevant decision is more likely to change attitudes towards the specified behavior [52]. Indeed, additional research conducted in the U.K., Iran, and Australia, found that messages highlighting the positive consequences of engaging in climate change mitigation activities were more effective at changing attitudes towards participating in 
pro-environmental behaviors than messages emphasizing the negative consequences of not engaging in climate change mitigation activities [53-55]. Thus, for promoting actual engagement in pro-environmental behaviors, existing research suggests that highlighting negative consequences tends to be more effective, although there is still no clear consensus. To our knowledge, no research has explored whether emphasizing positive or negative outcomes is more effective at discouraging red meat consumption specifically.

A separate type of message framing, emphasis framing, is focused on emphasizing a specific aspect or feature of a given issue (e.g., portraying climate change as an environmental issue versus a public health issue) [46]. A recent meta-analysis found that framing climate change as an opportunity for economic growth, an environmental hazard, or a moral issue modestly altered individuals' support for climate policy and intentions to engage in environmental behaviors [46]. It is currently unknown, however, whether emphasizing specific topics within the environmental frame at large (e.g., water shortages, biodiversity loss) affects individuals' intentions to participate in pro-climate behaviors such as reducing red meat consumption.

In addition, little is currently known about which audiences will be most responsive to meat-reduction focused messages. While existing messaging studies in high-income countries show that being female [56-61] and eating meat less regularly [56-58] tend to be consistent predictors of willingness to eat less meat, there is limited and inconsistent evidence regarding the effects of other demographic characteristics such as age, education, ethnicity, and income level [62].

The primary objective of this research is to explore the efficacy of goal framing for discouraging red meat purchases by experimentally testing whether messages that convey the worsening of environmental harms or the reduction of environmental harms are perceived as more effective at discouraging beef purchases. Perceived message effectiveness is a predictor of longer-term behavior change [63] and is a widely-used measure in initial testing of messages because it tends to be sensitive to small differences between similar messages [64-68]. Given the paucity of research on goal framing for messages focused on discouraging red meat consumption, this was an exploratory study and as such, we did not have an a priori hypothesis about which type of message would elicit higher effectiveness. As secondary goals, this study explores whether PME varies between seven different environmental topics (emphasis frames) or based on demographic characteristics.

\section{Materials and Methods}

\subsection{Sample}

Survey participants $(n=1088)$ were recruited through convenience sampling in October 2019 using CloudResearch Prime Panels as part of an experiment that tested the impact of sugar-sweetened beverage (SSB) warnings on SSB purchasing behavior and reactions among Latino and non-Latino parents. Prime Panels used purposive sampling to recruit half Latino and half non-Latino participants.

Utilizing online panels to recruit convenience samples has been found to generate experimental findings comparable to those from representative samples [69,70]. Inclusion criteria included residing in the U.S., being 18 or older, and having at least one child between 2 and 12. The latter criterion was included because the primary experiment focused on reactions to sugar-sweetened beverage warnings among parents. Participants received incentives in cash, gift cards, or rewards points from Prime Panels. The University of North Carolina (UNC) Institutional Review Board approved this study (IRB \#19-0277).

\subsection{Messages}

Message topics were chosen based on a high level of peer-reviewed and scientific organizations' (including the Intergovernmental Panel on Climate Change) evidence on the environmental harms of beef consumption and production. For each of the seven topics, message text was then developed to either highlight that purchasing beef can worsen environmental harms ("worsening harms" goal frame) or that purchasing less beef can 
reduce environmental harms ("reducing harms" goal frame). Message topics (the emphasis frames) were the within-subjects factor (Table 1). Participants were randomized to see messages in either the worsening harms or reducing harms frame (between-subjects factor).

Table 1. Text of Environmental Messages Tested in an Online Study of U.S. Adults $(n=1078)$.

\begin{tabular}{|c|c|}
\hline Frame 1: Worsening of Environmental Harms & Frame 2: Reduction of Environmental Harms \\
\hline Buying beef can ... & Buying less beef can ... \\
\hline increase your carbon footprint & reduce your carbon footprint \\
\hline increase greenhouse gas emissions & reduce greenhouse gas emissions \\
\hline contribute to water shortages & reduce water shortages \\
\hline hurt the environment & help the environment \\
\hline worsen climate change & help mitigate climate change \\
\hline contribute to biodiversity loss & reduce biodiversity loss \\
\hline contribute to deforestation & reduce deforestation \\
\hline
\end{tabular}

\subsection{Procedures}

This experiment was conducted online using Qualtrics and employed a mixed betweenwithin design. After completing informed consent, eligible participants first answered a series of questions about SSB warnings and SSB consumption. Participants then responded to one question about their beef consumption frequency before viewing seven randomly ordered messages about different environmental harms. For each of these seven messages, participants answered the same question about how much the message discouraged them from wanting to buy beef. Finally, participants answered several demographic questions.

\subsection{Measures}

Beef consumption frequency was measured using a modified NHANES item: "Thinking about the last month, how often did you typically consume beef (including steak, ground beef, or other types of beef)?" Response options included Never, Once a month, 2-3 times a month, Once a week, 2-6 times a week, Once a day, or More than once a day [71]. Discouragement from buying beef was measured using one item from the UNC PME Scale [72]: "How much does each statement discourage you from wanting to buy beef?" Response options were: not at all (coded as 1); a little bit (2); somewhat (3); quite a bit (4); and a great deal (5). PME is a common measure used in health-related message development and testing and has been found to predict behavioral change [73].

\subsection{Analysis}

Statistical analyses were conducted in Stata/SE 16.1 using two-tailed tests and a significance level of 0.05 (StataCorp LLC, College Station, TX, USA). A multilevel mixedeffects linear model with random intercepts at the respondent level was estimated to test for differences in PME between goal framing conditions (worsening of environmental harms vs. reduction of environmental harms) and message topics (climate change, deforestation, etc.). The dependent variable was PME and the independent variables were dummy variables for the worsening of harms framing condition (relative to reduction of harms) and for six of the seven message topics (relative to carbon footprint), and interactions between the worsening of harms framing condition dummy and each of the six message topic dummies. Using the model estimates, we then estimated the mean PME by framing condition on average over the seven message topics, and the difference in these means (the average framing effect). Similarly, we estimated the mean PME by message topic on average over the two framing conditions, and all pairwise differences in those means. To test whether the framing effect differed by message topic, we carried out a Wald test of joint significance of the coefficients on the interaction terms, with joint significance indicating that the framing effect did differ by message topic, i.e., was not homogenous across message topics. In further analyses, we estimated the average framing effect for each message topic separately. Results using a 
multilevel mixed-effects ordered logit model did not differ in any meaningful way with respect to the direction of findings and statistical significance.

To explore predictors of PME, PME was averaged over all seven topics and regressed using ordinary least squares (OLS) on categories of age, beef consumption frequency, education level, income level, Latino ethnicity, and gender. Demographic characteristics were categorized as follows-age: 18-29, 30-39, or over 39 years old; beef consumption frequency: eats beef more than once a week or less than once a week; education level: more than high school or less than high school; Latino ethnicity: yes or no; gender: man, woman, or transgender; and income level: less than $\$ 35,000$, between $\$ 35,000$ and $\$ 74,999$, or $\$ 75,000$ and above. These categorizations were chosen to create the most equal split between categories. Where an equal split was not possible in two categories (e.g., age and income level), three categories were created and two regression coefficients were reported.

\section{Results}

\subsection{Demographic Characteristics}

Participants' mean age was 35.3 years (Table 2$)$. More than half (58.3\%) identified as female and approximately half $(47.7 \%)$ were Latino, had a college degree or higher (52.5\%), and had an annual household income of less than $\$ 50,000$ (46.5\%). Regarding beef consumption, most $(65.0 \%)$ participants ate beef once a week or more.

Table 2. Descriptive Statistics of Sociodemographic Characteristics, Beef Consumption, and Language Preference of Participants in an Online Study of U.S. Adults $(n=1078)$.






\subsection{Message Framing Conditions}

The messages for both the worsening harms and reducing harms frames are shown in Table 1. The mean PME was 2.80 (95\% CI 2.70, 2.91) in the reducing harms framing condition and 2.89 (95\% CI 2.78, 2.99) in the worsening harms framing condition. Although this difference was not statistically significant $(p=0.277)$, it is notable that PME was on average higher in the worsening of harms frame than in the reduction of harms frame for all message topics (Figure 1). Figure 1 shows the mean PME for both messaging frames across each environmental message topic.

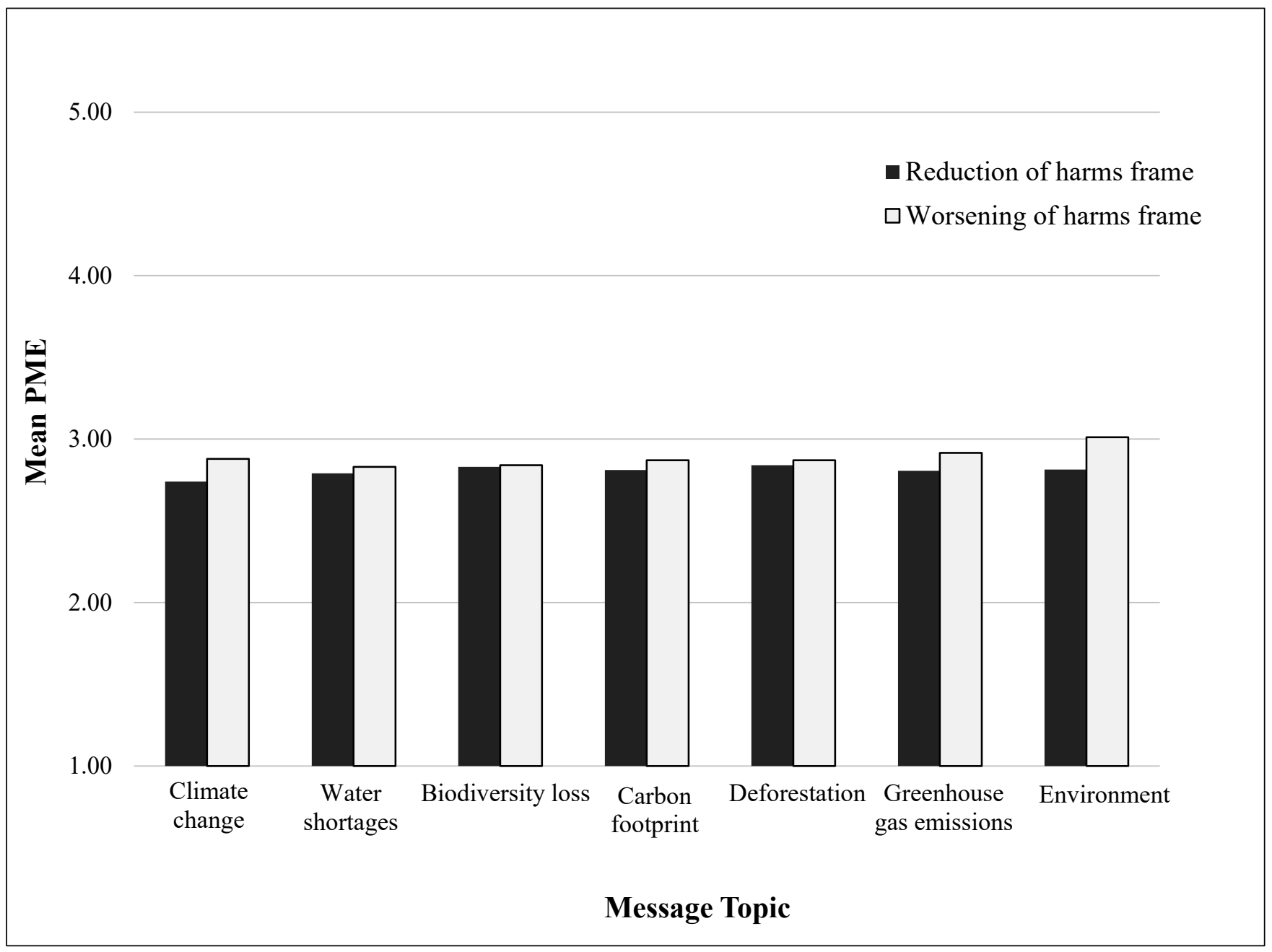

Figure 1. Perceived Message Effectiveness by Message Topic and Framing Condition in an Online Study of U.S. Adults $(n=1078)$.

The coefficients on the interactions between the worsening of harms frame dummy and the message topic dummies were jointly statistically significant $(p=0.004)$, rejecting the hypothesis of a homogenous framing effect across message topics. This result was driven by the mean PME difference between frames on 'environment' messages: 3.01 for the message 'buying beef can hurt the environment' vs. 2.81 for the message 'buying less beef can help the environment' $(p=0.017)$, while it was not statistically different from zero for the other message topics.

Mean PME ratings by message topic are displayed in Figure 2, and ranged from 2.81 (climate change, water shortages) to 2.91 (environment). The 'environment' message elicited statistically higher PME $(p<0.05)$ than all topics except GHG emissions. All other comparisons between topics were not statistically significant. Figure 2 shows the mean PME, averaged across both message frames, for each environmental message topic. 


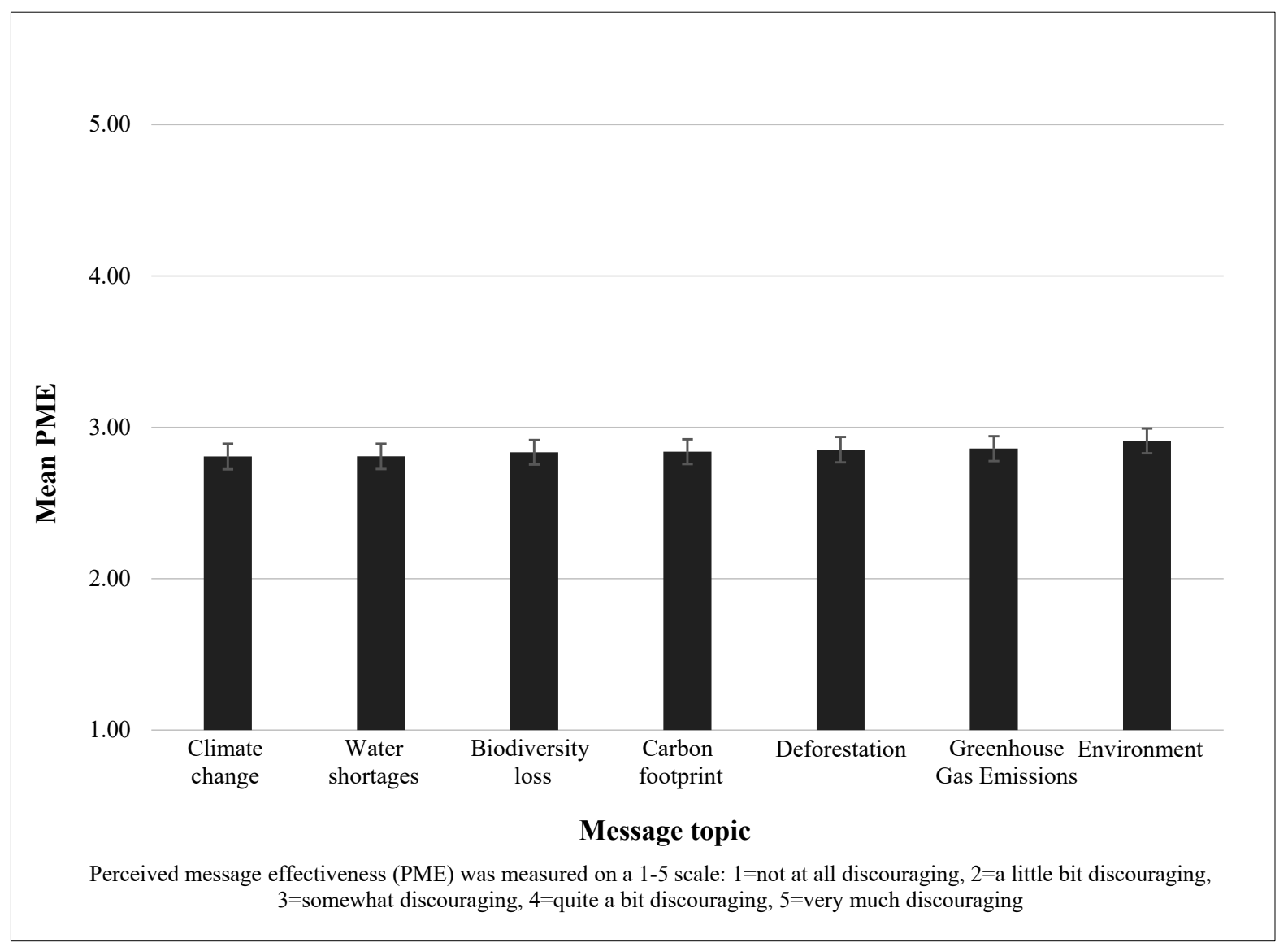

Figure 2. Perceived Message Effectiveness by Message Topic in an Online Study of U.S. Adults ( $n=1078)$.

\subsection{Demographic Predictors of PME}

The results of the OLS regression of average PME (averaged over the seven questions) on demographic characteristics are presented in Table 3.

Messages elicited lower PME among participants aged 40 years and older compared to participants aged $18-29(b=-0.10, p<0.05)$. Messages also elicited lower PME among participants who consumed beef more than once a week compared to those who consumed beef once a week or less $(b=-0.10, p<0.01)$. Participants who had completed more than a high school degree had higher PME ratings than participants who had completed high school or less $(b=0.10, p<0.01)$. Messages also elicited higher PME among Latino participants compared to non-Latino participants $(b=0.09, p<0.01)$.

Table 3. Results of Ordinary Least Squares Regression of Perceived Message Effectiveness on Demographic Covariates in an Online Study of U.S. Adults $(n=1078)$.

\begin{tabular}{ccccc}
\hline & Coefficient & $p$ Value & 95\% CI & $\begin{array}{c}\text { Standardized } \\
\text { Coefficient }\end{array}$ \\
\hline Aged over 39 (vs. between 18 and 29) & $-0.28^{*}$ & 0.013 & $-0.49,-0.06$ & -0.10 \\
Aged between 30 and 39 (vs. between 18 and 29) & -0.06 & 0.507 & $-0.25,0.12$ & -0.03 \\
Eats beef more than once a week (vs. once a week or less) & $-0.26^{* * *}$ & 0.001 & $-0.41,-0.11$ & -0.10 \\
More than high school (vs. high school or less) & $0.24^{* *}$ & 0.005 & $0.08,0.41$ & 0.10 \\
Latino ethnicity (vs. non Latino ethnicity) & $0.21^{* *}$ & 0.005 & $0.07,0.36$ & 0.09 \\
Male (vs. female) + & 0.06 & 0.455 & $-0.10,0.21$ & 0.02 \\
Income between $\$ 35,000$ and $\$ 74,999$ (vs. less than $\$ 35,000)$ & -0.02 & 0.842 & $-0.20,0.17$ & -0.01 \\
Income of $\$ 75,000$ or more (vs. less than $\$ 35,000)$ & 0.19 & 0.068 & $-0.01,0.40$ & 0.07 \\
\hline
\end{tabular}

${ }^{*} p<0.05,{ }^{* *} p<0.01,{ }^{* * *} p<0.001$. + We do not report the coefficient for transgender (relative to female, the reference gender category) due to small cell size $(n=5)$. 


\section{Discussion}

This study adds to the limited literature on environmental messages aimed at reducing beef consumption. This study found no statistically significant differences in PME between messages that highlighted the worsening or reduction of environmental harms. However, the pattern of results suggested that PME tended to be higher for messages that focused on worsening environmental harms compared to reducing environmental harms, although these differences were small. The exception was the message that emphasized that purchasing beef can "hurt the environment," which elicited greater PME than the message emphasizing that purchasing less beef can "help the environment." The message topic that elicited the strongest response from participants was the one that included the 'environment' topic and messages overall elicited the highest PMEs among participants that were Latino, less than 30 years old, ate beef once a week or less, and had a college or advanced degree.

The finding that the message frames describing either the worsening or reduction of environmental harms were equally discouraging is in contrast to existing research that has explored the impacts of goal framing in environmental messages. In a systematic review of 61 studies that investigated the use of goal framing to promote pro-environmental behaviors and attitudes, only 6 found that the effect of emphasizing negative or positive outcomes did not differ, whereas 30 studies found that emphasizing negative outcomes was more effective and 18 studies found that emphasizing positive outcomes was more effective [52]. Numerous other studies have also found that either highlighting positive consequences $[53-55,74]$ or negative consequences $[75,76]$ of a decision is more effective at promoting participation in environmentally friendly behaviors. Differences in the message content could help explain the contrast in findings, this being the first study to explore goal framing to discourage beef purchases specifically. Overall, the result that the two message frames equally discouraged beef purchasing across most topics suggests that multiple framing strategies may be effective for campaigns and other initiatives aimed at generating awareness about the environmental harms of red meat.

The message that included the 'environment' topic elicited greater discouragement than all other topic but 'greenhouse gas emissions' although the difference was small in magnitude. These findings suggest that employing a more general, straightforward term like 'the environment' is more persuasive for people who are less familiar with specific environmental harms like deforestation and water shortages. Further, the 'environment' is an overarching term that encompasses the specific harms. Thus, it may seem more important or salient to consumers compared to more specific harms.

The interaction of framing (reducing harms and worsening harms) with topic was driven by differences in framing with the 'environment' message topic. This topic had higher PME ratings when the message focused on the worsening of environmental harms as opposed to the reduction of environmental harms. This result is consistent with environmental communications research which has found that highlighting negative outcomes is more effective at promoting participation in pro-climate behaviors than highlighting positive outcomes [52] and supports the notion of a negativity bias wherein individuals dislike losses more than equivalent gains [49-51]. This finding is also consistent with SSB research, which has generally found that messages emphasizing the negative consequences (e.g., graphic warning labels) of SSB consumption are more effective than health-promoting logos at getting consumers to select lower sugar products [77-79]. We did not see this pattern among any other message topic besides the environment. Given that the awareness of environmental harms of red meat is low [62,80], the lack of variation in PME ratings across framing conditions for the other environmental topics could be due to participants having less baseline knowledge about those specific environmental harms, whereas helping or hurting the environment was easier to understand and interpret across frames. Future research should further explore the use of the term "environment" in messages aimed at reducing red meat purchasing and consumption. 
This experiment is the first that has tested the differences between Latino adults and non-Latino adults in messages related to reducing beef purchasing. Considering U.S. Latino populations consume the highest level of unprocessed red meat [81] compared to other ethnic groups, this demographic is important to assess. The finding that Latino adults rated messages as more discouraging compared to non-Latino adults is consistent with other research about Latino adults and the environment in general: Latino adults in the U.S. are more likely than non-Latino white adults to believe climate change is a problem that is human caused [82,83] and personally affecting them [82-86]. Considering a recent report found that individuals that were convinced global warming is happening, human caused, and an urgent threat were more willing to adopt a more plant-based diet [80], it is possible that Latino participants in our sample were more discouraged from buying red meat because of their stronger pro-environmental views and belief in human-caused climate change. Qualitative research could help further elucidate these relationships.

Our other findings examining the association between sociodemographic characteristics and PME ratings of the messages were consistent with previous literature. For example, the finding that participants below 30 years of age had higher PME ratings on average is consistent with research that has found that young people are more likely to know about the environmental harms of meat [87] and to eat less meat for environmental reasons [88]. People aged between 41 and 60, in contrast, are more likely to reduce meat consumption because of health concerns [88], suggesting that they may be less persuaded by environmental arguments to purchase less meat.

The result that participants that eat beef once a week or less were more discouraged by the messages compared to more regular beef consumers is consistent with prior research that has found that more frequent meat-eaters are less willing to reduce their meat consumption [56-58]. This finding also builds on research showing that reactance or resistance to persuasive messages may be more pronounced among those with higher engagement with the target behavior [89]. This difference could be due to more regular meat-eaters' greater preference for meat [90], enjoyment of meat [91], or belief that eating meat is a natural and normal human behavior [91]. This finding also supports the notion of a 'meat paradox,' wherein more regular meat-eaters resist information about the harms of meat consumption because they are in conflict to their values or behavior [91,92]. Regular beefeaters in our sample may have minimized the potential benefits of purchasing less beef instead of accepting personal responsibility, lowering PME. Belief that consuming meat is necessary for maintaining good health has also been identified as a persistent barrier for meat reduction among individuals from the U.S. and U.K. [91,93,94] despite research showing that balanced vegetarian diets are nutritionally adequate and healthful [95] and research documenting the significant health benefits that can result from adhering to diets higher in plant-based foods and lower in animal-based foods [96]. Red meat can also be culturally symbolic, representing strength and masculinity [97]. Combined, these factors may amplify resistance among frequent meat-eaters to purchase less meat.

Participants who had completed more than a high school degree had higher PME ratings than participants who had completed high school or less. Few studies have explored the effect of education on willingness to reduce meat purchases or consumption. Our findings are consistent with a nationally representative Dutch study that found that as education level increased, participants were more willing to eat meatless meals [97]. This finding complements other research that has found that having greater awareness of the environmental toll of meat increases willingness to eat less meat [62]. It may be that participants in our study with a higher education level were more discouraged from buying beef due to their greater knowledge of meat's environmental harms. However, we did not assess this knowledge of harms in our study. This relationship warrants further exploration.

Despite sizable research that has indicated that being female is a predictor of willingness to eat less meat [62], we observed no relationship between gender and PME in our study. Income level also had no effect on participants' PME ratings. 
Strengths of this study include that it was the first study to our knowledge to experimentally test perceived effectiveness of different environmental messages aimed at reducing red meat consumption and that it involved a large sample of U.S. adults. Additionally, the sample was approximately half Latino, which allowed a large enough sample to explore the association between Latino ethnicity and responsiveness to environmentally themed messages to reduce meat purchases.

Limitations of this study include that the messages were displayed and assessed in an online survey, and as such consumption and behavioral outcomes were not assessed. Moreover, the design, while allowing us to compare two types of goal frames, precluded the ability to compare messages to a control. We also did not evaluate participants' engagement level in other pro-environmental behaviors or emotional responses to the messages, both of which have been shown to influence which goal frame is more impactful at promoting pro-environmental behaviors $[48,49]$ and could have helped explain why both goal frames performed similarly in this study. Finally, we did not assess participants' baseline views on or knowledge of meat consumption and its effect on the environment, which would have helped to better contextualize the PME ratings overall. Future research should examine these types of messages in more detail (e.g., using qualitative methods) and test how they affect consumers' purchases of red meat in real-world settings.

\section{Conclusions}

Reducing beef consumption in the U.S. is critical for promoting human and planetary health. This study is one of the first that has explored the impact of goal or emphasis framing on messages aimed at reducing red meat consumption. We found that messages emphasizing that purchasing less beef reduces environmental harms performed similarly to messages emphasizing that purchasing beef worsens environmental harms. There were few differences between specific environmental topics (e.g., water shortages and greenhouse gas emissions), though the message focusing on 'the environment' at large elicited the greatest response from survey participants overall and seems promising for future messaging studies. To build on this finding, additional research should assess whether the term 'environment' is more familiar or understandable to consumers than more specific environmental harms. We also recommend directly testing the effectiveness of emphasis frames spanning across multiple topics (e.g., health and environment) to determine which frame overall is best at discouraging red meat consumption.

Populations that were over 39 years old, ate beef more than once a week, had a high school education or less, and were non-Latino were less responsive to the messages overall. Collectively, these findings suggest that to maximize the effectiveness of messages to reduce red meat consumption, employing different messaging tactics for different demographics may be a winning strategy. To assess this, future research should test the effectiveness of these messages across other subpopulations and explore how these messages affect consumers' purchases of red meat in real-world settings.

Author Contributions: A.W. led the conceptualization and design of this study with support from L.S.T. and M.G.H.; A.W. led initial manuscript preparation with support and contribution from L.S.T. and M.G.H.; M.B. led data analysis and contributed to manuscript preparation; L.S.T. and M.G.H. oversaw data collection and provided feedback and editing on drafts. All authors have read and agreed to the published version of the manuscript.

Funding: This work was funded through a grant from the Wellcome Trust, grant id \# 216042/Z/19/Z Grant \# K01HL147713 from the National Heart, Lung, and Blood Institute of the NIH supported M.G.H.'s time on this paper. The content is solely the responsibility of the authors and does not necessarily represent the official views of the NIH. We are grateful to the Carolina Population Center and its NIH Center grant (P2C HD050924) for general support. The survey data used in this study were supported by a grant from Healthy Eating Research, a national program of the Robert Wood Johnson Foundation. The views expressed here do not necessarily reflect the views of the Foundation. 
Institutional Review Board Statement: This study was conducted in accordance with the Declaration of Helsinki, and all procedures involving study participants were approved by the University of North Carolina Institutional Review Board (IRB \#19-0277).

Informed Consent Statement: Informed consent was obtained from all subjects involved in this study; after reading an online consent form, participants consented prior to starting the survey by clicking an agreement button at its beginning.

Data Availability Statement: Data will be shared upon request; those requesting access will be added to the UNC IRB before receiving data.

Acknowledgments: The authors thank Isabella Higgins for her logistical support in this study. The authors also thank Christina Chauvenet her for contributions.

Conflicts of Interest: The authors declare no conflict of interest.

\section{References}

1. Willett, W.; Rockström, J.; Loken, B.; Springmann, M.; Lang, T.; Vermeulen, S.; Garnett, T.; Tilman, D.; DeClerck, F.; Wood, A.; et al. Food in the Anthropocene: The EAT-Lancet Commission on healthy diets from sustainable food systems. Lancet 2019, 393, 447-492. [CrossRef]

2. Carr, P.; Walter, V.; Brenner, H.; Hoffmeister, M. Meat subtypes and their association with colorectal cancer: Systematic review and meta-analysis. Int. J. Cancer 2016, 138, 293-302. [CrossRef] [PubMed]

3. Sandhu, M.S.; White, I.R.; McPherson, K. Systematic Review of the Prospective Cohort Studies on Meat Consumption and Colorectal Cancer Risk: A Meta-Analytical Approach. Cancer Epidemiol. Biomark. Prev. 2001, 10, 439-446.

4. Collins, K. Reducing Colorectal Cancer Risk by Cutting Red Meat. American Institute for Cancer Research. 2019. Available online: https:/ / www.aicr.org/resources/blog/reducing-colorectal-cancer-risk-by-cutting-red-meat/ (accessed on 5 March 2020).

5. Aune, D.; Ursin, G.; Veierød, M.B. Meat consumption and the risk of type 2 diabetes: A systematic review and meta-analysis of cohort studies. Diabetologia 2009, 52, 2277-2287. [CrossRef] [PubMed]

6. Bechthold, A.; Boeing, H.; Schwedhelm, C.; Hoffmann, G.; Knüppel, S.; Iqbal, K.; De Henauw, S.; Michels, N.; Devleesschauwer B.; Schlesinger, S.; et al. Food groups and risk of coronary heart disease, stroke and heart failure: A systematic review and dose-response meta-analysis of prospective studies. Crit. Rev. Food Sci. Nutr. 2019, 59, 1071-1090. [CrossRef] [PubMed]

7. Rouhani, M.H.; Salehi-Abargouei, A.; Surkan, P.J.; Azadbakht, L.J.O.R. Is there a relationship between red or processed meat intake and obesity? A systematic review and meta-analysis of observational studies. Obes. Rev. 2014, 15, 740-748. [CrossRef] [PubMed]

8. Larsson, S.C.; Orsini, N. Red Meat and Processed Meat Consumption and All-Cause Mortality: A Meta-Analysis. Am. J. Epidemiol. 2014, 179, 282-289. [CrossRef]

9. Etemadi, A.; Sinha, R.; Ward, M.H.; Graubard, B.I.; Inoue-Choi, M.; Dawsey, S.M.; Abnet, C.C. Mortality from Different Causes Associated with Meat, Heme Iron, Nitrates, and Nitrites in the NIH-AARP Diet and Health Study: Population Based Cohort Study. BMJ 2017, 357, j1957. [CrossRef]

10. Rock, C.L.; Thomson, C.; Gansler, T.; Gapstur, S.M.; McCullough, M.L.; Patel, A.V.; Bandrews, K.S.; Bandera, E.V.; Spees, C.K.; Robien, K.; et al. American Cancer Society guideline for diet and physical activity for cancer prevention. CA A Cancer J. Clin. 2020, 70, 245-271. [CrossRef]

11. American Diabetes Association. Protein. Available online: https://www.diabetes.org/healthy-living/recipes-nutrition/eatingwell/protein (accessed on 12 December 2020).

12. Pan, A.; Sun, Q.; Bernstein, A.M.; Schulze, M.B.; E Manson, J.; Willett, W.C.; Hu, F.B. Red meat consumption and risk of type 2 diabetes: 3 cohorts of US adults and an updated meta-analysis. Am. J. Clin. Nutr. 2011, 94, 1088-1096. [CrossRef]

13. Ibsen, D.B.; Steur, M.; Imamura, F. Replacement of Red and Processed Meat With Other Food Sources of Protein and the Risk of Type 2 Diabetes in European Populations: The EPIC-InterAct Study. Diabetes Care 2020, 43, 2660-2667. [CrossRef] [PubMed]

14. Harvard Health. Cutting Red Meat-for a Longer Life. 2012. Available online: https://www.health.harvard.edu/staying-healthy/ cutting-red-meat-for-a-longer-life (accessed on 15 December 2020).

15. Fadnes, L.T.; Økland, J.-M.; Haaland, A.; Johansson, K.A. Estimating impact of food choices on life expectancy: A modeling study. PLOS Med. 2022, 19, e1003889. [CrossRef] [PubMed]

16. Gerber, P.J.; Steinfeld, H.; Henderson, B. Tackling Climate Change Through Livestock: A Global Assessment of Emissions and Mitigation Opportunities; Food and Agriculture Organization of the United Nations: Rome, Italy, 2013.

17. Godfray, H.C.J.; Aveyard, P.; Garnett, T. Meat consumption, health, and the environment. Science 2018, 361, eaam5324. [CrossRef]

18. Steinfeld, H.; Gerber, P.; Wassenaar, T.; Castel, V.; Rosales, M.; de Haan, C. Livestock's Long Shadow: Environmental Issues and Options; Food and Agriculture Organization of the United Nations: Rome, Italy, 2006.

19. Machovina, B.; Feeley, K.J.; Ripple, W.J. Biodiversity conservation: The key is reducing meat consumption. Sci. Total Environ. 2015, 536, 419-431. [CrossRef] [PubMed]

20. Bezner-Kerr, R.; McGuire, K.L.; Nigh, R.; Rocheleau, D.; Soluri, J.; Perfecto, I.; Hemming, D. Effects of industrial agriculture on climate change and the mitigation potential of small-scale agro-ecological farms. CAB Rev. 2011, 6, 1-18. 
21. Asner, G. Measuring Carbon Emissions from Tropical Deforestation: An Overview. Environmental Defense Fund. 2009. Available online: https://www.edf.org/sites/default/files/10333_Measuring_Carbon_Emissions_from_Tropical_Deforestation-An_Overview.pdf (accessed on 12 February 2020).

22. Chai, B.C.; van der Voort, J.R.; Grofelnik, K.; Eliasdottir, H.G.; Klöss, I.; Perez-Cueto, F.J. Which Diet Has the Least Environmental Impact on Our Planet? A Systematic Review of Vegan, Vegetarian and Omnivorous Diets. Sustainability 2019, 11, 4110. [CrossRef]

23. Poore, J.; Nemecek, T. Reducing food's environmental impacts through producers and consumers. Science 2018, 360, 987-992. [CrossRef]

24. Aiking, H.; de Boer, J. The next protein transition. Trends Food Sci. Technol. 2020, 105, 515-522. [CrossRef]

25. OECD Meat Consumption (Indicator). Available online: https:// data.oecd.org/agroutput/meat-consumption.htm (accessed on 10 April 2020).

26. Searchinger, T.; Waite, R.; Hanson, C.; Ranganathan, J.; Dumas, P.; Matthews, E.; Klirs, C. Creating a Sustainable Food Future: A Menu of 50 Solutions to Feed Nearly 10 Billion People by 2050; World Resources Institute: Washington, DC, USA, 2019.

27. Ranganathan, J.; Vennard, D.; Waite, R.; Lipinski, B.; Searchinger, T.; Dumas, P. Shifting Diets for a Sustainable Food Future. 2016. Available online: https:/ / www.wri.org/research/shifting-diets-sustainable-food-future (accessed on 27 January 2022).

28. Garnett, T. Cooking Up a Storm: Food, Greenhouse Gas Emissions and our Changing Climate; Center for Environmental Strategy, University of Surrey: Food Climate Research Network: Guildford, UK, 2008.

29. Eshel, G.; Shepon, A.; Makov, T.; Milo, R. Land, irrigation water, greenhouse gas, and reactive nitrogen burdens of meat, eggs, and dairy production in the United States. Proc. Natl. Acad. Sci. USA 2014, 111, 11996-12001. [CrossRef]

30. Shukla, P.R.; Skea, J.; Calvo Buendia, E.; Masson-Delmotte, V.; Pörtner, H.-O.; Roberts, D.C.; Zhai, P.; Slade, R.; Connors, S.; van Diemen, R.; et al. Summary for Policymakers. In Climate Change and Land: An IPCC Special Report on Climate Change, Desertification, Land Degradation, Sustainable Land Management, Food Security, and Greenhouse Gas Fluxes in Terrestrial Ecosystems; Intergovernmental Panel on Climate Change: Geneva, Switzerland, 2019.

31. Rockström, J.; Stordalen, G.A.; Horton, R. Acting in the Anthropocene: The EAT-Lancet Commission. Lancet 2016, 38, $2364-2365$. [CrossRef]

32. McMichael, A.J.; Powles, J.W.; Butler, C.D.; Uauy, R. Food, livestock production, energy, climate change, and health. Lancet 2007, 370, 1253-1263. [CrossRef]

33. Hedenus, F.; Wirsenius, S.; Johansson, D.J.A. The importance of reduced meat and dairy consumption for meeting stringent climate change targets. Clim. Chang. 2014, 124, 79-91. [CrossRef]

34. Hallström, E.; Carlsson-Kanyama, A.; Börjesson, P. Environmental impact of dietary change: A systematic review. J. Clean Prod. 2015, 91, 1-11. [CrossRef]

35. Sun, Z.; Scherer, L.; Tukker, A.; Spawn-Lee, S.A.; Bruckner, M.; Gibbs, H.K.; Behrens, P. Dietary change in high-income nations alone can lead to substantial double climate dividend. Nat. Food 2022, 3, 29-37. [CrossRef]

36. EAT. EAT-Lancet Commission Brief for Everyone. Available online: https://eatforum.org/lancet-commission/ eatinghealthyandsustainable/ (accessed on 25 January 2022).

37. Eisen, M.B.; Brown, P.O. Rapid global phaseout of animal agriculture has the potential to stabilize greenhouse gas levels for 30 years and offset 68 percent of $\mathrm{CO}_{2}$ emissions this century. PLOS Climate 2020, 1, e0000010. [CrossRef]

38. Clark, M.A.; Domingo, N.G.; Colgan, K.; Thakrar, S.K.; Tilman, D.; Lynch, J.; Hill, J.D. Global food system emissions could preclude achieving the $1.5^{\circ}$ and $2{ }^{\circ} \mathrm{C}$ climate change targets. Science 2020, 370, 705-708. [CrossRef]

39. Tilman, D.; Clark, M.; Williams, D.R.; Kimmel, K.; Polasky, S.; Packer, C. Future threats to biodiversity and pathways to their prevention. Nature 2017, 546, 73-81. [CrossRef]

40. Noar, S.M.; Hall, M.G.; Francis, D.B.; Ribisl, K.M.; Pepper, J.K.; Brewer, N.T. Pictorial cigarette pack warnings: A meta-analysis of experimental studies. Tob. Control 2016, 25, 341-354. [CrossRef]

41. Grummon, A.H.; Hall, M.G. Sugary drink warnings: A meta-analysis of experimental studies. PLoS Med. 2020, 17, e1003120. [CrossRef]

42. Clarke, N.; Pechey, E.; Kosīte, D.; König, L.M.; Mantzari, E.; Blackwell, A.K.; Marteau, T.; Hollands, G. Impact of health warning labels on selection and consumption of food and alcohol products: Systematic review with meta-analysis. Health Psychol. Rev. 2020, 15, 430-453. [CrossRef]

43. Leiserowitz, A.; Maibach, E.; Rosenthal, S.; Kotcher, J.; Bergquist, P.; Ballew, M.; Goldberg, M.; Gustafson, A.; Wang, X. Climate Change in the American Mind: April 2020; Yale University and George Mason University, Yale Program on Climate Change Communication: New Haven, CT, USA, 2020.

44. Ballew, M.; Marlon, J.; Kotcher, J.; Maibach, E.; Rosenthal, S.; Bergquist, P.; Leiserowitz, A. Young Adults, Across Party Lines, Are More Willing to Take Climate Action; Yale University and George Mason University, Yale Program on Climate Change Communication: New Haven, CT, USA, 2020.

45. Cordts, A.; Nitzko, S.; Spiller, A. Consumer Response to Negative Information on Meat Consumption in Germany. Int. Food Agribus. Manag. Rev. 2014, 17, 83-106.

46. Li, N.; Su, L.Y.F. Message Framing and Climate Change Communication: A Meta-Analytical Review. J. Appl. Commun. 2018. [CrossRef]

47. Nisbet, M.C. Communicating Climate Change: Why Frames Matter for Public Engagement. Environ. Sci. Policy 2009, 51, 12-23. [CrossRef] 
48. Van de Velde, L.; Verbeke, W.; Popp, M.; Van Huylenbroeck, G. The importance of message framing for providing information about sustainability and environmental aspects of energy. Energy Policy 2010, 38, 5541-5549. [CrossRef]

49. Cheng, T.; Woon, D.K.; Lynes, J.K. The Use of Message Framing in the Promotion of Environmentally Sustainable Behaviors. Soc. Mar. Q. 2011, 17, 48-62. [CrossRef]

50. Kahneman, D.D.; Tversky, A. Prospect Theory: An Analysis of Decision under Risk. Econometrica 1979, 47, 263-291. [CrossRef]

51. Meyerowitz, B.E.; Chaiken, S. The effect of message framing on breast self-examination attitudes, intentions, and behavior. J. Pers. Soc. Psychol. 1987, 52, 500-510. [CrossRef]

52. Homar, A.R.; Cvelbar, L.K. The effects of framing on environmental decisions: A systematic literature review. Ecol. Econ. 2021, 183, 106950. [CrossRef]

53. Hurlstone, M.J.; Lewandowsky, S.; Newell, B.; Sewell, B. The Effect of Framing and Normative Messages in Building Support for Climate Policies. PLoS ONE 2014, 9, e114335. [CrossRef]

54. Mir, H.M.; Behrang, K.; Isaai, M.T.; Nejat, P. The impact of outcome framing and psychological distance of air pollution consequences on transportation mode choice. Transp. Res. Part D Transp. Environ. 2016, 46, 328-338. [CrossRef]

55. Spence, A.; Pidgeon, N. Framing and communicating climate change: The effects of distance and outcome frame manipulations. Glob. Environ. Chang. 2010, 20, 656-667. [CrossRef]

56. De Boer, J.; de Witt, A.; Aiking, H. Help the climate, change your diet: A cross-sectional study on how to involve consumers in a transition to a low-carbon society. Appetite 2016, 98, 19-27. [CrossRef] [PubMed]

57. De Boer, J.; Schösler, H.; Aiking, H. “Meatless days" or “less but better"? Exploring strategies to adapt Western meat consumption to health and sustainability challenges. Appetite 2014, 76, 120-128. [CrossRef] [PubMed]

58. De Groeve, B.; Bleys, B. Less Meat Initiatives at Ghent University: Assessing the Support among Students and How to Increase It. Sustainability 2017, 9, 1550. [CrossRef]

59. Schösler, H.; de Boer, J.; Boersema, J.J.; Aiking, H. Meat and masculinity among young Chinese, Turkish and Dutch adults in the Netherlands. Appetite 2015, 89, 152-159. [CrossRef]

60. Tobler, C.; Visschers, V.H.M.; Siegrist, M. Eating green. Consumers' willingness to adopt ecological food consumption behaviors. Appetite 2011, 57, 674-682. [CrossRef]

61. Verain, M.C.D.; Dagevos, H.; Antonides, G. Sustainable food consumption. Product choice or curtailment? Appetite 2015, 91, 375-384. [CrossRef]

62. Sanchez-Sabate, R.; Sabaté, J. Consumer Attitudes Towards Environmental Concerns of Meat Consumption: A Systematic Review. Int. J. Environ. Res. Public Health 2019, 16, 1220. [CrossRef]

63. Baig, S.A.; Noar, S.M.; Gottfredson, N.C.; Lazard, A.J.; Ribisl, K.M.; Brewer, N.T. Incremental criterion validity of message perceptions and effects perceptions in the context of anti-smoking messages. J. Behav. Med. 2021, 44, 74-83. [CrossRef]

64. Grummon, A.H.; Hall, M.G.; Taillie, L.S.; Brewer, N.T. How should sugar-sweetened beverage health warnings be designed? A randomized experiment. Prev. Med. 2019, 121, 158-166. [CrossRef]

65. Hall, M.G.; Lazard, A.J.; Grummon, A.H.; Higgins, I.C.; Bercholz, M.; Richter, A.P.C.; Taillie, L.S. Designing warnings for sugary drinks: A randomized experiment with Latino parents and non-Latino parents. Prev. Med. 2021, 148, 106562. [CrossRef]

66. Hall, M.G.; Grummon, A.H.; Lazard, A.J.; Maynard, O.M.; Taillie, L.S. Reactions to graphic and text health warnings for cigarettes, sugar-sweetened beverages, and alcohol: An online randomized experiment of US adults. Prev. Med. 2020, 137, 106120. [CrossRef] [PubMed]

67. Taillie, L.S.; Chauvenet, C.; Grummon, A.H.; Hall, M.G.; Waterlander, W.; Prestemon, C.E.; Jaacks, L.M. Testing front-of-package warnings to discourage red meat consumption: A randomized experiment with US meat consumers. Int. J. Behav. Nutr. Phys. Act. 2021, 18, 1-13. [CrossRef] [PubMed]

68. Taillie, L.S.; Hall, M.G.; Gómez, L.F.; Higgins, I.; Bercholz, M.; Murukutla, N.; Mora-Plazas, M. Designing an Effective Front-ofPackage Warning Label for Food and Drinks High in Added Sugar, Sodium, or Saturated Fat in Colombia: An Online Experiment. Nutrients 2020, 12, 3124. [CrossRef] [PubMed]

69. Crump, M.J.C.; McDonnell, J.V.; Gureckis, T.M. Evaluating Amazon's Mechanical Turk as a Tool for Experimental Behavioral Research. PLoS ONE 2013, 8, e54710. [CrossRef]

70. Pauszek, J.R.; Sztybel, P.; Gibson, B.S. Evaluating Amazon's Mechanical Turk for psychological research on the symbolic control of attention. Behav. Res. 2017, 49, 1969-1983. [CrossRef]

71. Centers for Disease Control and Prevention. National Center for Health Statistics (2009-2010) National Health and Nutrition Dietary Screener Questionnaire; U.S. Department of Health and Human Services, Centers for Disease Control and Prevention: Hyattsville, MD, USA, 2019. Available online: https:/ / epi.grants.cancer.gov/diet/shortreg/instruments/dsq-in-nhanes-09-10-intervieweradministered-english-version.pdf (accessed on 4 August 2019).

72. Baig, S.A.; Noar, S.M.; Gottfredson, N.C.; Boynton, M.H.; Ribisl, K.M.; Brewer, N.T. UNC Perceived Message Effectiveness: Validation of a Brief Scale. Ann. Behav. Med. 2018, 53, 732-742. [CrossRef]

73. Noar, S.M.; Barker, J.; Bell, T.; Yzer, M. Does Perceived Message Effectiveness Predict the Actual Effectiveness of Tobacco Education Messages? A Systematic Review and Meta-Analysis. Health Commun. 2020, 35, 148-157. [CrossRef]

74. Kim, S.B.; Kim, D.Y. The Effects of Message Framing and Source Credibility on Green Messages in Hotels. Cornell. Hosp. Q. 2014, 55, 64-75. [CrossRef] 
75. Davis, J.J. The Effects of Message Framing on Response to Environmental Communications. J. Mass. Commun. Q. 1995, 72, 285-299. [CrossRef]

76. Blose, J.E.; Mack, R.W.; Pitts, R.E. The Influence of Message Framing on Hotel Guests' Linen-Reuse Intentions. Cornell. Hosp. Q. 2015, 56, 145-154. [CrossRef]

77. De Alcantara, M.; Ares, G.; de Castro, I.P.L.; Deliza, R. Gain vs. loss-framing for reducing sugar consumption: Insights from a choice experiment with six product categories. Food Res. Int. 2020, 136, 109458. [CrossRef] [PubMed]

78. Rosenblatt, D.H.; Bode, S.; Dixon, H.; Murawski, C.; Summerell, P.; Ng, A.; Wakefield, M. Health warnings promote healthier dietary decision making: Effects of positive versus negative message framing and graphic versus text-based warnings. Appetite 2018, 127, 280-288. [CrossRef] [PubMed]

79. Vidal, G.; Machín, L.; Aschemann-Witzel, J.; Ares, G. Does message framing matter for promoting the use of nutritional warnings in decision making? Public Health Nutr. 2019, 22, 3025-3034. [CrossRef]

80. Leiserowitz, A.; Ballew, M.; Rosenthal, S. Climate Change and the American Diet; Yale University and Earth Day Network, Yale Program on Climate Change Communication: New Haven, CT, USA, 2020.

81. Zeng, L.; Ruan, M.; Liu, J.; Wilde, P.; Naumova, E.N.; Mozaffarian, D.; Zhang, F.F. Trends in Processed Meat, Unprocessed Red Meat, Poultry, and Fish Consumption in the United States, 1999-2016. J. Acad. Nutr. Diet. 2019, 119, 1085-1098. [CrossRef] [PubMed]

82. Ballew, M.T.; Goldberg, M.H.; Rosenthal, S.A.; Cutler, M.J.; Leiserowitz, A. Climate Change Activism Among Latino and White Americans. Front. Commun. 2019, 3, 375-384. [CrossRef]

83. Leiserowtiz, A.; Cutler, M.; Rosenthal, S. Climate Change in the Latino Mind; Yale University, Yale Program on Climate Change Communication: New Haven, CT, USA, 2017.

84. The New York Times, Stanford University, Resources for the Future. Global Warming National Poll. 2015. Available online: https:/ / s3.amazonaws.com/s3.documentcloud.org/documents/1658128/global-warming-hispanics-poll.pdf (accessed on 11 March 2020).

85. Environmental Defense Fund. Latinos Communities and Climate Change: Why we Care and What We Can Do. Available online: https://www.edf.org/sites/default/files/content/latinos_and_climate_change_factsheet_0317_refresh.pdf (accessed on 10 March 2020).

86. Vargas, E.D. Latinos and Climate Change. Latino Decisions. 2020. Available online: https://latinodecisions.com/wp-content/ uploads /2020/02/CA-TX-LD-Poll-Final-Slide-Deck.pdf (accessed on 10 March 2020).

87. Dibb, S.; Fitzpatrick, I. Let's Talk about Meat: Changing Dietary Behavior for the 21st Century. Eating Better. 2014. Available online: https:/ / www.eating-better.org/uploads/Documents/LetsTalkAboutMeat.pdf (accessed on 9 February 2020).

88. Pribis, P.; Pencak, R.C.; Grajales, T. Beliefs and Attitudes toward Vegetarian Lifestyle across Generations. Nutrients 2010, 2 , 523-531. [CrossRef] [PubMed]

89. Hall, M.G.; Sheeran, P.; Noar, S.M.; Ribisl, K.M.; Bach, L.E.; Brewer, N.T. Reactance to Health Warnings Scale: Development and Validation. Ann. Behav. Med. 2016, 50, 736-750. [CrossRef]

90. Graça, J.; Oliveira, A.; Calheiros, M.M. Meat, beyond the plate. Data-driven hypotheses for understanding consumer willingness to adopt a more plant-based diet. Appetite 2015, 90, 80-90. [CrossRef]

91. Piazza, J.; Ruby, M.B.; Loughnan, S.; Luong, M.; Kulik, J.; Watkins, H.M.; Seigerman, M. Rationalizing meat consumption. The 4Ns. Appetite 2015, 91, 114-128. [CrossRef] [PubMed]

92. Stoll-Kleemann, S.; Schmidt, U.J. Reducing meat consumption in developed and transition countries to counter climate change and biodiversity loss: A review of influence factors. Reg. Environ. Change 2017, 17, 1261-1277. [CrossRef]

93. Campbell, J.; Macdiarmid, J.I.; Douglas, F. Young people's perception of the environmental impact of food and their willingness to eat less meat for the sake of the environment: A qualitative study. Proc. Nutr. Soc. 2016, 75, E224. [CrossRef]

94. Macdiarmid, J.I.; Douglas, F.; Campbell, J. Eating like there's no tomorrow: Public awareness of the environmental impact of food and reluctance to eat less meat as part of a sustainable diet. Appetite 2016, 96, 487-493. [CrossRef] [PubMed]

95. Craig, W.J.; Mangels, A.R. Position of the American Dietetic Association: Vegetarian diets. J. Am. Diet. Assoc. 2009, 109, 1266-1282.

96. Kim, H.; Caulfield, L.E.; Garcia-Larsen, V.; Steffen, L.M.; Coresh, J.; Rebholz, C.M. Plant-Based Diets Are Associated With a Lower Risk of Incident Cardiovascular Disease, Cardiovascular Disease Mortality, and All-Cause Mortality in a General Population of Middle-Aged Adults. J. Am. Heart Assoc. 2019, 8, 16. [CrossRef]

97. De Boer, J.; Schösler, H.; Boersema, J.J. Climate change and meat eating: An inconvenient couple? J. Environ. Psychol. 2013, 33, 1-8. [CrossRef] 